7. Reprod. Fert. (1967) 13, 199-203

\title{
ASSAY OF THE ANTI-OESTROGENIC EFFECTS OF PROGESTAGENS IN WOMEN
}

\author{
HARRY W. RUDEL, THOMAS LEBHERZ, \\ MANUEL MAQUEO-TOPETE, JORGE MARTINEZ-MANAUTOU \\ AND STUART BESSLER \\ Syntex Research, Institute of Clinical Medicine, Palo Alto, California, and \\ Centro de Investigacion Sobre Fertilidad y Esterilidad, Mexico, D.F.
}

(Received 18th Fanuary 1966)

\begin{abstract}
Summary. An assay to determine the anti-oestrogenic potency of progestagens in women is described. The progressive increase in endometrial glandular suppression with increasing doses of progestagens is the basis of the assay. Norethindrone (oestrogen free) is three times as potent as chlormadinone acetate with a $95 \%$ confidence limit of 2.3 to 4.0. This is in contrast to the greater secretory potency of chlormadinone acetate. It is suggested that the anti-oestrogenic action of progestagens is of some importance in the selection of compounds for contraceptives of the combined progestagen-oestrogen, and of great importance for those of the continuous low dose progestagen types. This property may also be desirable in the treatment of both endometrial hyperplasia and adenocarcinoma.
\end{abstract}

\section{INTRODUCTION}

The progestagen component of the progestagen-oestrogen oral contraceptive mixtures produces secretory exhaustion of the endometrial glands and exerts a restraint upon their development and maturation (Maqueo-Topete, PerezVega, Goldzieher, Martinez-Manautou \& Rudel, 1963). Thus, at the conclusion of a 20-day regimen with one of these agents, the endometrial histology may vary from complete absence of glandular secretion and tortuosity to one of suppressed activity, with some cellular or intraluminal secretion and minimal to moderate tortuosity. In no case is there a fully developed secretory endometrium characteristic of the late luteal phase of the menstrual cycle. This inhibitory effect has been thought to be due to the anti-oestrogenic property of the progestagen in that complete glandular suppression has been prevented by beginning the progestagen-oestrogen therapy on Day 10 of the menstrual cycle rather than on Day 5, allowing for five additional days of endogenous oestrogen stimulation of the endometrium (Rudel, Maqueo-Topete \& MartinezManautou, 1964). That this is a special property unrelated to the classical luteal effect of the progestagens is further emphasized by studies showing that this picture of endometrial inhibition can be achieved with doses of progestagens even less than those required to evoke secretory changes in the oestrogen-primed 
endometrial glands (Rudel \& Kincl 1966). In order to give further support to this concept we undertook to investigate two progestagens of different secretory potency, chlormadinone acetate and norethindrone. The former compound has been shown to be five times as potent as the latter in studies in women (Martinez-Manautou, Maqueo-Topete, Gilbert \& Goldzieher, 1962). Data obtained from the Clauberg assay in rabbits also support the greater potency of chlormadinone acetate as a progestagen (Kincl, 1961; Kincl \& Folch-Pi, 1962). Norethindrone, on the other hand, is about ten times more potent than chlormadinone acetate as an anti-oestrogen in the mouse antiuterotrophic assay (Dorfman, Kincl \& Ringold, 1961; Dorfman \& Kincl, 1963).

\section{MATERIALS AND METHODS}

Women of known fertility and with regular menstrual cycles were treated for one cycle with one of the following: chlormadinone acetate, $0.2,0.3,0.4,0.5$, 1.0 and $4.0 \mathrm{mg}$; norethindrone (oestrogen free), $0.05,0.1,0.2,0.25,0.5$ and $1.0 \mathrm{mg}$. Therapy was given in a single daily oral dose for 20 days, starting on Day 5 of the menstrual cycle. A biopsy was taken from each patient between

TABle 1

HISTOLOGICAL CLASSIFICATION OF ENDOMETRIUM

\begin{tabular}{l|l}
\hline $\begin{array}{c}\text { Increasing anti-oestrogenic } \\
\text { activity }\end{array}$ & \\
\hline 0 Secretory & $\begin{array}{l}\text { Normal histological appearance } \\
\text { Normal histological appearance } \\
\text { Discrete to moderate tortuosity and secretion } \\
1 \text { Irregular secretory }\end{array}$ \\
2 Irregular & $\begin{array}{l}\text { Discrete tortuosity and absence of secretion } \\
\text { Absence of tortuosity and secretion }\end{array}$ \\
\hline
\end{tabular}

the 21 st and 27 th day. The specimens were fixed in cold formalin $\left(4^{\circ} \mathrm{C}\right)$, sectioned and stained with haematoxylin and eosin. They were classified as proliferative, secretory, irregular secretory, irregular and inactive endometria. The anatomical bases for these classifications are given in Table 1. We have assumed that a normal datable secretory endometrium or a proliferative endometrium following a 20-day cyclic course of progestagen treatment results when the progestagens fail to exert an effect on the endometrium (Rudel $e$ t al., 1964). An arbitrary value of zero has been assigned to them. Irregular secretory, irregular and inactive endometria are the consequence of increasing inhibitory effects of the progestagens, and in turn have been given values of 1,2 and 3 plus, respectively. An index of response for each dose was calculated as a weighted average of the values. The assay data were analysed using statistical procedures described by Finney (1960).

\section{RESULTS}

The data are summarized in Tables 2 and 3. The indices of response are graphically presented in Text-fig. 1. The results of the analysis indicate that 
norethindrone is three times as potent as chlormadinone. A $95 \%$ confidence interval for the potency ratio is $2 \cdot 3$ to $4 \cdot 0$. The narrowness of the interval supports the precision of this assay.

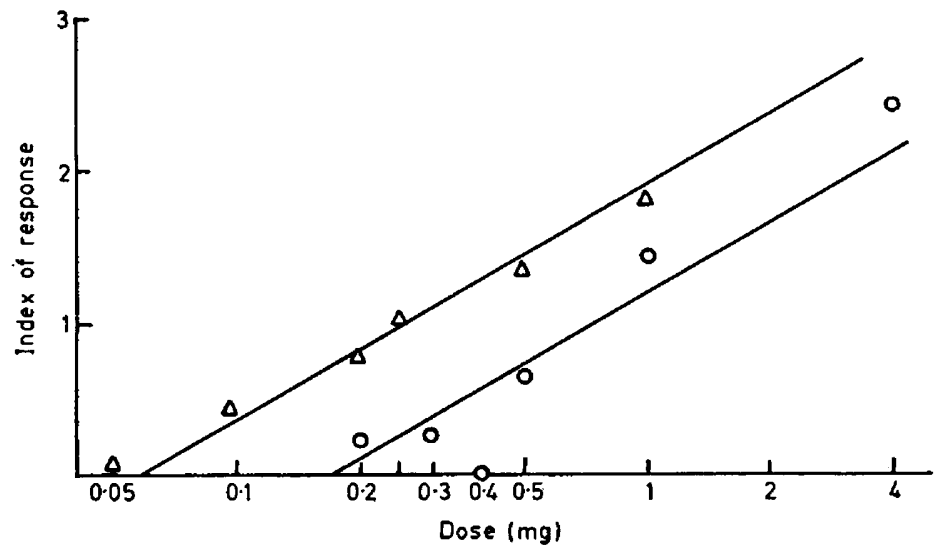

TExT-Fig. 1. Potency ratio $=3 \cdot 0 ; 95 \%$ confidence interval $=2 \cdot 3$ to $4 \cdot 0$. $\Delta$, Norethindrone; O, chlormadinone.

TABLE 2

ENDOMETRIAL GLANDULAR INHIBITION: NORETHINDRONE

\begin{tabular}{|c|c|c|c|c|c|c|}
\hline & $\begin{array}{c}0 \\
\text { Secretory }\end{array}$ & $\begin{array}{c}0 \\
\text { Proliferative }\end{array}$ & $\begin{array}{c}1 \\
\text { Irregular } \\
\text { secretory }\end{array}$ & $\begin{array}{c}2 \\
\text { Irregular }\end{array}$ & $\begin{array}{c}3 \\
\text { Inactive }\end{array}$ & $\begin{array}{c}\text { Index } \\
\text { of } \\
\text { response }\end{array}$ \\
\hline $\begin{array}{l}0.05 \mathrm{mg} \\
0.1 \mathrm{mg} \\
0.2 \mathrm{mg} \\
0.25 \mathrm{mg} \\
0.5 \mathrm{mg} \\
1.0 \mathrm{mg}\end{array}$ & $\begin{array}{r}11 \\
18 \\
3 \\
1 \\
1 \\
0\end{array}$ & $\begin{array}{r}4 \\
11 \\
0 \\
0 \\
0 \\
0\end{array}$ & $\begin{array}{r}1 \\
15 \\
4 \\
3 \\
5 \\
2\end{array}$ & $\begin{array}{r}0 \\
1 \\
1 \\
1 \\
16 \\
9\end{array}$ & $\begin{array}{l}0 \\
1 \\
0 \\
0 \\
0 \\
0\end{array}$ & $\begin{array}{l}0.06 \\
0.43 \\
0.75 \\
1.00 \\
1.37 \\
1.82\end{array}$ \\
\hline
\end{tabular}

TABLE 3

ENDOMETRIAL GLANDULAR INHIBITION: GHLORMADINONE

\begin{tabular}{|c|c|c|c|c|c|c|}
\hline & $\begin{array}{c}0 \\
\text { Secretory }\end{array}$ & $\begin{array}{c}0 \\
\text { Proliferative }\end{array}$ & $\begin{array}{c}1 \\
\text { Irregular } \\
\text { secretory }\end{array}$ & $\begin{array}{c}2 \\
\text { Irregular }\end{array}$ & $\begin{array}{c}3 \\
\text { Inactive }\end{array}$ & $\begin{array}{l}\text { Index } \\
\text { of } \\
\text { response }\end{array}$ \\
\hline $\begin{array}{l}0.2 \mathrm{mg} \\
0.3 \mathrm{mg} \\
0.4 \mathrm{mg} \\
0.5 \mathrm{mg} \\
1.0 \mathrm{mg} \\
4.0 \mathrm{mg}\end{array}$ & $\begin{array}{r}10 \\
1 \\
19 \\
2\end{array}$ & $\begin{array}{l}1 \\
2 \\
4 \\
9\end{array}$ & $\begin{array}{r}3 \\
1 \\
\\
14 \\
2 \\
2\end{array}$ & $\begin{array}{l}9 \\
4 \\
3\end{array}$ & $\begin{array}{l}1 \\
7\end{array}$ & $\begin{array}{c}0.21 \\
0.25 \\
0 \\
0.63 \\
1.44 \\
2.42\end{array}$ \\
\hline
\end{tabular}

\section{DISCUSSION}

These studies show that the inhibition of glandular development is directly related to the doses of norethindrone and chlormadinone acetate, but that their anti-oestrogenic potencies are unrelated to their relative endometrial glandular 
secretory activity in women. For the production of fully developed secretory changes in the oestrogen-primed endometrium, norethindrone is used in a daily dose of $10 \mathrm{mg}$ for 10 to 14 days (Boschann, 1958) whereas with chlormadinone acetate only $2 \mathrm{mg}$ a day are required for the same period (Martinez-Manautou et al., 1962). In the case of norethindrone, as little as $0.5 \mathrm{mg}$ a day will produce endometrial glandular inhibition quite consistently. The separation between anti-oestrogenic and secretory actions is not as great with chlormadinone acetate. In the initial development of oral contraceptives of the combined progestagen-oestrogen type, it was the practice to base the quantity of the progestagen in the mixture on its secretory potency. If the full antifertility effect is to be maintained with reduced dosages of progestagen, enough of the latter must be retained to produce endometrial suppression, and a cervical mucus hostile to spermatozoal penetration (Rudel, Martinez-Manautou \& Maqueo-Topete, 1965) in addition to suppression of ovulation. These present studies give a biological basis for the selection of this dose of the progestagen. It is quite obvious that if a given dosage of progestagen administered alone for a 20-day period fails to produce endometrial suppression, when it is combined with enough oestrogen to suppress ovulation the oestrogen effect will predominate in the endometrium and the cervical mucus. We have shown this to be the case in endometrial studies with the combined use of chlormadinone acetate $(0.5 \mathrm{mg})$ plus mestranol $(0.08 \mathrm{mg})$, as well as with norethynodrel $(2.5 \mathrm{mg})$ plus mestranol $(0.10 \mathrm{mg})$. Proliferative endometria were found with both combinations after 20 days of treatment starting on cycle Day 5 (Rudel et al., 1965). With our recent interest in low dosage continuous progestagen contraceptive regimes (Martinez-Manautou, Cortez, Giner, Aznar, Casasola \& Rudel, 1966) this assay has become even more important in the selection of progestational compounds and their appropriate doses. We have also suggested that the anti-oestrogenic property of progestagens is the therapeutically desirable feature to be sought in an agent for the symptomatic management of endometrial hyperplasia. Further, these compounds should be given for a long enough period to produce endometrial glandular atrophy. This may be particularly vital in the older woman who exhibits endometrial hyperplasia. Similarly, this anti-oestrogenic function of progestagens is probably the important biological feature in the usefulness of these agents in the management of endometrial adenocarcinoma.

\section{REFERENCES}

Boschann, H.-W. (1958) Observations on the role of progestational agents in human gynecologic disorders and pregnancy complications. Ann. N.Y. Acad. Sci. 71, 727.

Dorfman, R. I., Kincl, F. A. \& Ringold, H. J. (1961) Anti-estrogen assay of neutral steroids administered by subcutaneous injection. Endocrinology, 68, 17 .

Dorfman, R. I. \& Kincl, F. A. (1963) Steroid anti-estrogens. Steroids, 1, 185.

FINNEY, D. J. (1960) Statistical methods in biological assay. Hafner, New York.

KincL, F. A. (1961) Steroids CLV. Progestatin Werkasamkeit von 6-substituierten 17 alpha-acetoxyprogesteron-Derivaten. Endokrinologie, 40, 257.

KincL, F. A. \& Folch-PI, A. (1962) Actividad progestational de derivados del pregnano (Administrados por via bucal). Ciencia, Méx. 22, 31 .

Maqueo-Topete, M., Perez-Vega, E., Goldzieher, J. W., Martinez-Manautou, J. \& Rudel, H. W. (1963) Comparison of the endometrial activity of three synthetic progestins used in fertility control. Am. 7. Obstet. Gynec. 85, 427. 
Martinez-Manautou, J., Cortez, V., Giner, J., Aznar, R., Gasasola, J. \& Rudel, H. W. (1966) Low doses of progestogen as an approach to fertility control. Fert. Steril. 17, 1.

Martinez-Manautou, J., Maqueo-Topete, M., Gilbert, R. A. \& Goldziener, J. W. (1962) Human endometrial activity of several new derivatives of 17 -acetoxyprogesterone. Fert. Steril. $13,169$.

Rudel, H. W. \& KincL, F. A. (1966) Biology of anti-fertility steroids. Acta endocr., Copenh. Suppl. 105.

Rudel, H. W., Maqueo-Topete, M. \& Martinez-Manautou, J. (1964) Correlation between the state of growth of the human endometrium and its response to a synthetic progestagen (Chlormadinone). F. Reprod. Fert. 8, 305.

Rudel, H. W., Martinez-Manautou, J. \& Maqueo-Topete, M. (1965) The role of progestogens in the hormonal control of fertility. Fert. Steril. 16, 158. 